University of Nebraska - Lincoln

DigitalCommons@University of Nebraska - Lincoln

Faculty Publications, Department of Psychology

Psychology, Department of

2012

Clozapine, but not olanzapine, disrupts conditioned avoidance response in rats by antagonizing $5-\mathrm{HT}_{2} \mathrm{~A} / 2 \mathrm{C}$ receptors

\author{
Ming Li \\ University of Nebraska-Lincoln, mli2@unl.edu \\ Tao Sun \\ University of Nebraska-Lincoln \\ Alexa Mead \\ University of Nebraska-Lincoln
}

Follow this and additional works at: https://digitalcommons.unl.edu/psychfacpub

Part of the Psychiatry and Psychology Commons

Li, Ming; Sun, Tao; and Mead, Alexa, "Clozapine, but not olanzapine, disrupts conditioned avoidance response in rats by antagonizing 5-HT2A/2C receptors" (2012). Faculty Publications, Department of Psychology. 561.

https://digitalcommons.unl.edu/psychfacpub/561

This Article is brought to you for free and open access by the Psychology, Department of at DigitalCommons@University of Nebraska - Lincoln. It has been accepted for inclusion in Faculty Publications, Department of Psychology by an authorized administrator of DigitalCommons@University of Nebraska - Lincoln. 


\title{
Clozapine, but not olanzapine, disrupts conditioned avoidance response in rats by antagonizing $5-\mathrm{HT}_{2 \mathrm{~A} / 2 \mathrm{C}}$ receptors
}

\author{
Ming Li, Tao Sun, and Alexa Mead \\ Department of Psychology, University of Nebraska-Lincoln, 238 Burnett Hall, Lincoln, NE 68588, USA \\ Corresponding author - Ming Li, email: $\underline{\text { mli2@unl.edu }}$
}

\begin{abstract}
The present study was designed to assess the role of $5-\mathrm{HT}_{2 \mathrm{~A} / 2 \mathrm{C}}$ receptors in the acute and repeated effect of clozapine and olanzapine in a rat conditioned avoidance response model, a validated model of antipsychotic activity. Male Sprague-Dawley rats that were previously treated with either phencyclidine (0.5-2.0 mg/kg, sc), amphetamine (1.25-5.0 mg/ kg, sc), or saline and tested in a prepulse inhibition of acoustic startle study were used. They were first trained to acquire avoidance response to a white noise (CS1) and a pure tone (CS2) that differed in their ability to predict the occurrence of footshock. Those who acquired avoidance response were administered with clozapine $(10.0 \mathrm{mg} / \mathrm{kg}, \mathrm{sc})$ or olanzapine $(1.0 \mathrm{mg} / \mathrm{kg}, \mathrm{sc})$ together with either saline or 1-2,5-dimethoxy-4-iodo-amphetamine (DOI, a selective $5-\mathrm{HT}_{2 \mathrm{~A} / 2 \mathrm{C}}$ agonist, 1.0 or $2.5 \mathrm{mg} / \mathrm{kg}$, $\mathrm{sc})$, and their conditioned avoidance responses were tested for four consecutive days. After two drug-free retraining days, the long-term repeated effect was assessed in a challenge test during which all rats were injected with a low dose of clozapine (5 mg/ $\mathrm{kg}, \mathrm{sc})$ or olanzapine $(0.5 \mathrm{mg} / \mathrm{kg})$. Results show that pretreatment of DOI dose-dependently reversed the acute disruptive effect of clozapine on both CS1 and CS2 avoidance responses, whereas it had little effect in reversing the acute effect of olanzapine. On the challenge test, pretreatment of DOI did not alter the clozapine-induced tolerance or the olanzapine-induced sensitization effect. These results confirmed our previous findings and suggest that clozapine, but not olanzapine, acts on through $5-\mathrm{HT}_{2 \mathrm{~A} / 2 \mathrm{C}}$ receptors to achieve its acute avoidance disruptive effect and likely its therapeutic effects. The long-term clozapine tolerance and olanzapine sensitization effects appear to be mediated by non-5- $\mathrm{HT}_{2 \mathrm{~A} / 2 \mathrm{C}}$ receptors.
\end{abstract}

Keywords: Clozapine, Olanzapine, 2,5-Dimethoxy-4-iodoamphetamine, Repeated antipsychotic treatment, $\mathrm{D}_{2 / 3}$ receptor, $5-\mathrm{HT}_{2 \mathrm{~A} / 2 \mathrm{C}}$ receptor, Conditioned avoidance response, Sensitization, Tolerance

\section{Introduction}

In behavioral pharmacology, the conditioned avoidance response (CAR) model is routinely used as a preclinical test for antipsychotic activity (Arnt 1982). In a typical experiment, a rat is placed in a two-compartment shuttle box and presented with a neutral conditioned stimulus (CS) such as a light or tone, followed by an aversive unconditioned stimulus (US), such as a footshock. The animal may escape the US by running from one compartment to the other. However, after several presentations of the CS-US pairing, the animal typically runs during the CS and before the onset of the US, thereby avoiding the US altogether. Rats acutely treated with low doses (non-cataleptic) of antipsychotic drugs (APDs) often fail to acquire or perform avoidance responses to the CS, whereas their escape responses to the US are less affected (Ader and Clink 1957; Wadenberg and Hicks 1999). This feature is shared by all clinically approved antipsychotic drugs, but not by anxiolytics or antidepressants (Mead et al. 2008; Sun et al. 2010).

In recent years, we have expanded the use of this model to study the behavioral and neurochemical mechanisms of action of antipsychotic drugs ( $\mathrm{Li}$ et al. 2007, 2009a, b, 2010; Mead and Li 2010). We also focus on the long-term (repeated) effect of antipsychotic treatment. One interesting finding comes from our recent study ( $\mathrm{Li}$ et al. 2010). In this study, we compared the acute and repeated effects of clozapine and olanzapine, two atypical antipsychotic drugs. We found that although acute administration of both drugs produces a similar disruptive effect on conditioned avoidance responding, repeated administration of clozapine produces a tolerance-like ef- 
fect (i.e. a gradual decrease in disrupting avoidance over time), whereas repeated administration of olanzapine produces a sensitization-like effect (a gradual increase in disrupting avoidance over time). We also showed that pretreatment of 1-2,5-dimethoxy-4-iodo-amphetamine (DOI, a selective $5-\mathrm{HT}_{2 \mathrm{~A} / 2 \mathrm{C}}$ agonist, $2.5 \mathrm{mg} / \mathrm{kg}$, sc), but not quinpirole (a selective dopamine $\mathrm{D}_{2 / 3}$ agonist, $1.0 \mathrm{mg} / \mathrm{kg}$, sc), attenuated the acute clozapine-induced disruption of avoidance responding, whereas pretreatment of quinpirole, but not DOI, attenuated that effect of olanzapine. On the repeated effects, pretreatment of DOI had no effect on either clozapine-induced tolerance or olanzapine-induced sensitization. In contrast, pretreatment of quinpirole attenuated the potentiated disruption of olanzapine, but enhanced the tolerance-like effect of clozapine. Based on these findings on doubly dissociated receptor mechanisms, we suggest that acute clozapine disrupts avoidance response primarily by blocking $5-\mathrm{HT}_{2 \mathrm{~A} / 2 \mathrm{C}}$ receptors, whereas acute olanzapine appears to exert its disruptive effect primarily by blocking dopamine $\mathrm{D}_{2}$ receptors. Both clozapine-induced tolerance and olanzapine-induced sensitization are likely mediated by $\mathrm{D}_{2 / 3}$ receptor, but not by $5-\mathrm{HT}_{2 \mathrm{~A} / 2 \mathrm{C}}$ receptor.

Because olanzapine, like clozapine, also possesses a potent antagonism on the $5-\mathrm{HT}_{2 \mathrm{~A} / 2 \mathrm{C}}$ receptor in addition to a relatively weak antagonism on $\mathrm{D}_{2}$ receptor (Meltzer et al. 2003), it is thus surprising that $5-\mathrm{HT}_{2 \mathrm{~A} / 2 \mathrm{C}}$ receptor is not found to be involved in the acute effect of olanzapine and it does not seem to play little role in the repeated effects of both drugs. These behavioral and neurochemical similarities and differences between the acute and repeated effects of clozapine and olanzapine warrant further investigation. The present study was designed to further assess the role of the $5-\mathrm{HT}_{2 \mathrm{~A} / 2 \mathrm{C}}$ receptor in the acute and repeated effect of clozapine and olanzapine to ensure that our previous findings are not artifacts and can be generalized to different animals and across different testing conditions. In the present study, we used heterogeneous groups of animals that had prior experience with either amphetamine, phencyclidine (PCP), or saline, as opposed to normal drug-naïve animals. These amphetamine- and PCP-pretreated rats had been shown to exhibit a deficit in the prepulse inhibition (PPI) of acoustic startle (Li et al. 2011), one of the most studied cognitive deficits associated with schizophrenia. Thus, they could be considered as putative "schizophrenic-like" animals (Geyer et al. 2001; Russig et al. 2003). In addition, we used a modified CAR paradigm involving two types of CS (CS1: a white noise and CS2: a pure tone), as opposed to just the CS1 used in our previous work (Li et al. 2010). We created these two types of CS signals that varied in their motivational salience (e.g. ability to elicit avoidance) and ability to predict the occurrence of an US footshock. This was achieved by pairing the CS1 with the US in every CS1 trial while pairing the CS2 with the US in only half of the CS2 trials if the rats failed to respond. This novel paradigm provides an additional measure of antipsychotic drug treatment on avoidance responding. We have used this paradigm to examine the behavioral mechanisms of antipsychotic action (Li et al. 2009b; Zhang et al. 2011) and aberrant behavioral responding in animal models of schizophrenia (Li et al. 2008; Chen et al. 2011).

\section{Materials and methods}

\section{Animals}

Subjects were male Sprague-Dawley rats (226-250 g upon arrival) purchased from Charles River Inc. (Portage, MI). They had been used in a separate study in which they were repeatedly treated with either amphetamine $(1.25-5.0 \mathrm{mg} / \mathrm{kg})$, PCP $(0.5-2.0 \mathrm{mg} / \mathrm{kg})$ or vehicle and tested for PPI of acoustic startle response once daily for six consecutive days (Li et al. 2011). None of them had any antipsychotic drug experience prior to this study and there was at least a 2-week interval between the last amphetamine or PCP experience and the first antipsychotic treatment. Rats were housed two per cage, in $48.3 \mathrm{~cm} \times 26.7 \mathrm{~cm} \times 20.3 \mathrm{~cm}$ transparent polycarbonate cages under 12-h light/dark conditions (light on between 6:30 a.m. and 6:30 p.m.). Room temperature was maintained at $22 \pm 1^{\circ} \mathrm{C}$ with a relative humidity of $50-60 \%$. Food and water were available ad libitum. Animals were allowed at least 1 week of habituation to the animal facility before being used in experiments. All procedures were approved by the Institutional Animal Care and Use Committee at the University of Nebraska-Lincoln.

Two-way avoidance conditioning apparatus

Eight identical two-way shuttle boxes custom designed and manufactured by Med Associates (St. Albans, VT) were used. Each box was housed in a ventilated, sound-insulated isolation cubicle $(96.52 \mathrm{~cm} \mathrm{~W} \times 35.56 \mathrm{~cm} \mathrm{D} \times 63.5 \mathrm{~cm} \mathrm{H})$. Each box was $64 \mathrm{~cm}$ long, $30 \mathrm{~cm}$ high (from grid floor), and $24 \mathrm{~cm}$ wide, and was divided into two equal-sized compartments by a partition with an arch style doorway $(15 \mathrm{~cm}$ high $\times 9 \mathrm{~cm}$ wide at base). A barrier $(4 \mathrm{~cm}$ high) was placed between the two compartments, so the rats had to jump from one compartment to the other. The grid floor consisted of 40 stainless-steel rods with a diameter of $0.48 \mathrm{~cm}$, spaced $1.6 \mathrm{~cm}$ apart center to center, 
through which a scrambled footshock (US, $0.8 \mathrm{~mA}$, maximum duration $5 \mathrm{~s}$ ) was delivered by a constant current shock generator (Model ENV-410B) and scrambler (Model ENV-412). Illumination was provided by two houselights mounted at the top of each compartment. The conditioned stimuli (either a $76 \mathrm{~dB}$ white noise CS1 or a $85 \mathrm{~dB} 2,800 \mathrm{~Hz}$ pure tone CS2) were produced by a speaker (ENV 224 AMX) mounted on the ceiling of the cubicle, centered above the shuttle box. Background noise (approximately $74 \mathrm{~dB}$ ) was provided by a ventilation fan affixed at the top corner of each isolation cubicle. All training and testing procedures were controlled by Med Associates programs running on a computer.

\section{Drugs}

Clozapine (CLZ) and olanzapine (OLZ) (gifts from NIMH drug supply program) were dissolved in $1.0 \%$ glacial acetic acid in distilled water. DOI (RBI-Sigma, Natick, MA) was dissolved in $0.9 \%$ saline. All drugs were administered subcutaneously in a volume of $1.0 \mathrm{ml} / \mathrm{kg}$ body weight. Choices of drug doses for CLZ and OLZ were based on our previous studies showing that at the chosen doses; both produce a reliable and comparable disruption of avoidance responding (Li et al. 2004a, 2009a, b, 2010; Mead and Li 2010), and they give rise to clinical levels of striatal $\mathrm{D}_{2}$ occupancy (50-80\%) at these doses (Kapur et al. 2003). The doses of DOI were chosen based on our recent work showing that DOI at $2.5 \mathrm{mg} / \mathrm{kg}$ reversed the avoidance-disruptive effect (Li et al. 2010) and the maternal-disruptive effect of clozapine (Zhao and Li 2009). Previous work also showed that DOI produces maximal behavioral effects between 2 and $3 \mathrm{mg} / \mathrm{kg}$ (Schreiber et al. 1995; Granoff and Ashby 1998; Halberstadt et al. 2009).

\section{Experiment 1: Effects of DOI pretreatment on clozapine-induced CS1 and CS2 avoidance disruption}

Sixty rats previously used in the PPI study (Li et al. 2011) were used in this experiment. In that study, one group of rats $(n=12)$ was repeatedly injected with saline and tested for PPI daily for six consecutive days. The second group $(n=12)$ was repeatedly injected with $4.0 \mathrm{mg} / \mathrm{kg}$ amphetamine for six consecutive days. The third group was injected with $1.25 \mathrm{mg} / \mathrm{kg}$ amphetamine on day $1-2,2.5 \mathrm{mg} / \mathrm{kg}$ on day $3-4$, and $5.0 \mathrm{mg} /$ $\mathrm{kg}$ on day 5-6. The fourth group was repeatedly injected with $2.0 \mathrm{mg} / \mathrm{kg}$ phencyclidine throughout the six consecutive days. Last, the fifth group was injected with $0.5 \mathrm{mg} / \mathrm{kg}$ phencyclidine on day $1-2,1.0 \mathrm{mg} / \mathrm{kg}$ on day $3-4$ and $2.0 \mathrm{mg} / \mathrm{kg}$ on day $5-6$.
Thirteen days after the last PPI test, all rats were trained in the modified two-way avoidance conditioning task for a total of ten sessions over a 2-week period. Each training session consisted of 30 trials. Ten trials (CS1 trials) used a 10-s 76-dB white noise as the CS with its termination immediately followed by the shock $(0.8 \mathrm{~mA}$, maximum duration $5 \mathrm{~s})$ if the rats did not make an avoidance response. The remaining 20 trials (CS2 trials) used a pure tone $(10 \mathrm{~s}, 2,800 \mathrm{kHz}$, $85 \mathrm{~dB})$ as the CS. In ten CS2 trials, the CS2 was followed by the shock if the rat failed to respond to the CS2, whereas, in another ten trials, there was no shock following the CS2. The ten CS1 trials were randomly intermixed with the 20 CS2 trials. During each trial, if a subject moved from one compartment into the other within the 10-s CS presentation, that CS was immediately terminated, the shock was prevented, and this shuttling response was recorded as avoidance (termed CS1 avoidance or CS2 avoidance). If the rat remained in the same compartment for more than $10 \mathrm{~s}$ and made a crossing upon receiving the footshock, this response was recorded as escape. If the rat did not respond during the entire 5-s presentation of the shock, the trial was terminated and escape failure was recorded. At the end of training session, 46 rats had reached training criterion ( $\geq 7$ CS1 avoidances and at least one CS2 avoidance in the last two training sessions: mean number of CS1 avoidance $=9.39+0.13$ and mean number of CS2 avoidance $=13.09+0.59$ ). We did not find any prior amphetamine or PCP treatment effect on the acquisition of CS1 avoidance $(F(4,55)=1.131, p=0.351)$ or CS2 avoidance $(F(4,55)=1.592, p=0.189)$. The welltrained rats were then randomly assigned to one of four groups: $\mathrm{VEH}+\mathrm{VEH}(n=11$, saline + sterile water), VEH + CLZ $(n=12)$, DOI $-1.0 \mathrm{mg} / \mathrm{kg}+\mathrm{CLZ}$ $(n=12)$, and DOI-2.5 mg/kg + CLZ $(n=11)$, and tested daily under the CS-only condition (no shock, ten CS1 trials, and 20 CS2 trials) for four consecutive days. During each test, rats were first pretreated with DOI $1.0 \mathrm{mg} / \mathrm{kg}$, $2.5 \mathrm{mg} / \mathrm{kg}$ (sc) or saline followed by an injection of sterile water (VEH), or CLZ $10.0 \mathrm{mg} /$ $\mathrm{kg}$ (sc) 10 min later. Thirty minutes after the second injection, rats were placed in the CAR boxes and tested. One day after the last drug test, all rats were tested drug-free for one session under the CS-only (no shock) condition and retrained for one session under the CSUS condition to bring their avoidance back to the predrug level. A final drug challenge test was conducted $24 \mathrm{~h}$ after the retraining session to assess the long-term effect of repeated antipsychotic treatment on avoidance. During the test, all rats were injected with CLZ $5.0 \mathrm{mg} / \mathrm{kg}$ and tested $1 \mathrm{~h}$ later in the same CAR procedure as used in the drug testing phase. 


\section{Experiment 2: Effects of DOI pretreatment on olanzapine-induced CS1 and CS2 avoidance disruption}

Thirty-six rats previously used in a PPI study were used in this experiment. Among them, 12 rats were repeatedly injected with saline and tested for PPI daily for six consecutive days. The second group $(n=12)$ was repeatedly injected with $0.5 \mathrm{mg} / \mathrm{kg}$ phencyclidine and the third group $(n=12)$ was repeatedly injected with $1.0 \mathrm{mg} / \mathrm{kg}$ phencyclidine and tested for PPI daily for six consecutive days. Eighteen days after the last PPI test, rats were trained in the modified CAR task for ten sessions. At the end of the training phase, 29 rats reached the training criterion (mean number of CS1 avoidance $=9.10+0.21$ and mean number of CS2 avoidance $=13.28+0.64$ ), and their prior drug experience was not a factor in the acquisition of CS1 avoidance $(F(2,33)=1.551, p=0.227)$ or CS2 avoidance $(F(4$, $55)=2.047, p=0.145)$. Rats were then randomly assigned to the following three groups: VEH + VEH (saline + sterile water, $n=9)$, VEH + OLZ $(1.0 \mathrm{mg} / \mathrm{kg}$, $n=10)$, and DOI- $2.5 \mathrm{mg} / \mathrm{kg}+$ OLZ $(1.0 \mathrm{mg} / \mathrm{kg}, n=10)$, and were subjected to four sessions of drug testing, two sessions of drug-free testing/retraining and a final drug challenge test, following the exact same schedule as described in "Experiment 1". During the challenge test, all rats were injected with OLZ $0.5 \mathrm{mg} / \mathrm{kg}$.

\section{Statistical analysis}

Avoidance response data were expressed as mean \pm SEM. Data on the four drug test sessions were analyzed using a repeated measures analysis of variance (ANOVA) with the between-subjects factor being the treatment (group) and the within-subjects factor being test session. Data for CS1 and CS2 avoidance were analyzed separately. Individual one-way ANOVAs followed by Tukey post hoc tests were used to detect group differences on each drug test session and the final challenge session. A conventional two-tailed level of significance at the $5 \%$ level was used.

\section{Results}

\section{Experiment 1: effects of DOI pretreatment on clozapine-} induced CS1 and CS2 avoidance disruption

As can be seen in Figure 1, CLZ treatment suppressed CS1 and CS2 avoidance responses throughout the four drug test sessions. Pretreatment of DOI dose-dependently reversed this effect of CLZ, and the DOI reversal
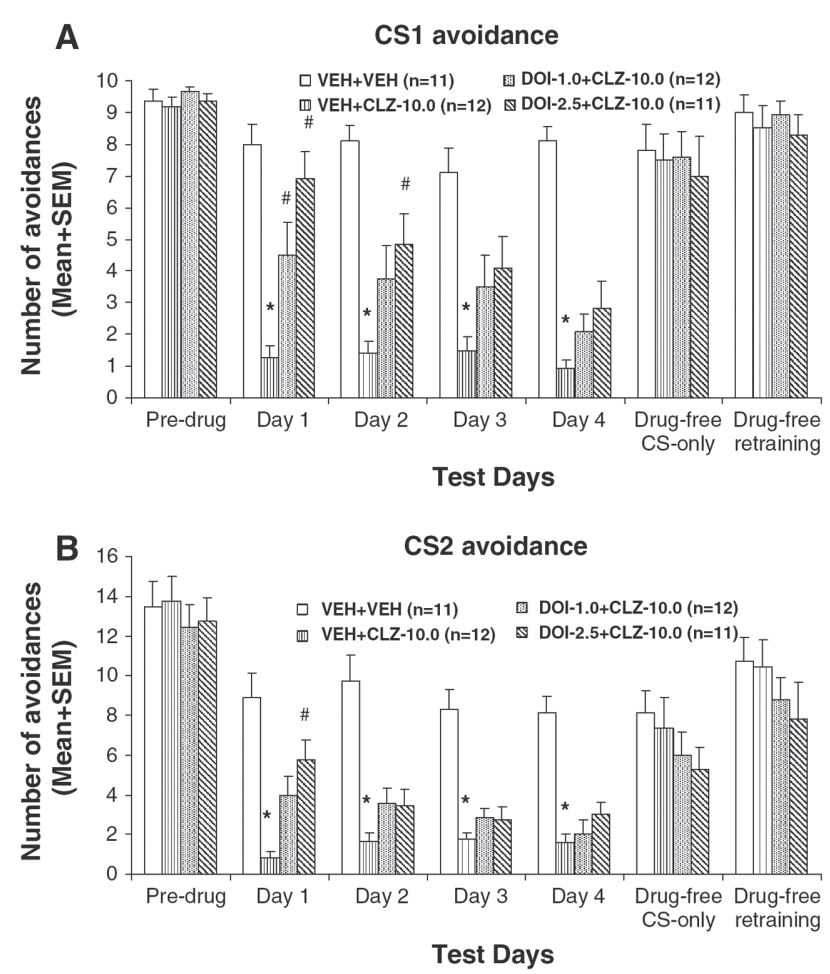

Figure 1. Effects of pretreatment of DOI on acute clozapineinduced disruption of CS1 avoidance (a) and CS2 avoidance (b). Mean (+SEM) numbers of avoidance responses of the four groups of rats on the last CAR training day (pre-drug), four drug test days (Day 1 to Day 3), and two drug-free test days (drug-free CS-only and drug-free retraining). ${ }^{*} p<0.05$ significantly different from the VEH $+\mathrm{VEH}$ group; $\# p<0.05$ significantly different from the VEH + CLZ group

effect tended to decrease over the drug test sessions. Repeated-measures ANOVA on the number of CS1 avoidance indicated a main effect of group, $F(3,42)=24.008$, $p<0.001$, session, $F(3,126)=6.318, p=0.001$, and a significant interaction between group and test session, $F(9$, $126)=2.223, p=0.025$. For the CS2 avoidance, repeated measures ANOVA also revealed a main effect of group, $F(3,42)=27.353, p<0.001$, session, $F(3,126)=3.721$, $p=0.013$, and a significant interaction between group and test session, $F(9,126)=1.978, p=0.047$.

One-way ANOVAs followed by Tukey post hoc tests were used to examine group differences on each drug test session. On the CS1 avoidance, the VEH + CLZ group differed significantly from the $\mathrm{VEH}+\mathrm{VEH}$ group on every drug day (all $p s<0.001$ ). It also differed significantly from the DOI-2.5 + CLZ group on day 1 , $p<0.001$ and day 2, $p=0.019$, and differed significantly from the DOI-1.0 + CLZ group on day $1, p=0.020$. On the CS2 avoidance, the VEH + CLZ group differed significantly from the vehicle group on every drug day (all $p$ s $<0.001$ ), but it only differed significantly from the DOI-2.5 + CLZ group on day $1, p<0.003$. Overall, re- 
sults from the drug test phase suggest that pretreatment of DOI dose-dependently reversed the CLZ-induced disruption of avoidance responding. This reversal effect was transient in nature and tended to diminish with repeated drug administration. It also showed a preferential action against CLZ disruption on CS1 avoidance (a response to a more salient stimulus) over CS2 avoidance (a response to a less salient stimulus).

On the two drug-free sessions, there was no significant group effect on either CS1 or CS2 avoidance (all $p s>0.412)$. However, on the drug challenge test during which all rats were acutely injected with CLZ at $5.0 \mathrm{mg} /$ $\mathrm{kg}$ (Figure 2), those that were previously treated with CLZ only (i.e. the VEH + CLZ rats) made more avoidance responses than the vehicle rats treated with CLZ for the first time, indicating that prior CLZ treatment caused a decreased response to CLZ (a tolerance effect). One-way ANOVA revealed a main effect of group on the CS1 avoidance, $F(3,42)=2.936, p=0.044$, and the CS2 avoidance $F(3,42)=3.072, p=0.038$. Post-hoc tests indicated that the VEH + CLZ group differed significantly from the VEH + VEH group on the CS2 avoidance, $p=0.033$. Pretreatment of DOI failed to alter the tolerance effect of repeated CLZ treatment, as there was no significant group difference between the VEH + CLZ group and the other two DOI pretreated groups (all ps $>0.0128$ ).

\section{Experiment 2: effects of DOI pretreatment on olanzapine-induced CS1 and CS2 avoidance disruption}

OLZ $1.0 \mathrm{mg} / \mathrm{kg}$ suppressed avoidance response on the first drug day and progressively enhanced its suppression over the 4-day drug test period (Figure 3). The disruptive effect of OLZ did not seem to be affected by pretreatment of DOI. Repeated measures ANOVA on the number of CS1 avoidance indicated a main effect of group, $F(2,26)=198.946, p<0.001$, session, $F(3$, $78)=7.238, p<0.001$, and a significant interaction between group and test session, $F(6,78)=4.797, p<0.001$. For the CS2 avoidance, repeated measures ANOVA also revealed a main effect of group, $F(2,26)=41.160$, $p<0.001$, session, $F(3,78)=12.223, p<0.001$, and a significant interaction between group and test session, $F(6$, $78)=2.620, p=0.023$.

One-way ANOVAs followed by Tukey post hoc tests revealed that the two OLZ groups (i.e. VEH + OLZ and DOI-2.5 + OLZ) did not differ from each other on both the CS1 and CS2 avoidances (all ps > 0.498), but differed significantly from the VEH + VEH group on every drug day (all $p \mathrm{~s}<0.001$ ), suggesting that pretreatment of DOI was ineffective in reversing the OLZ-induced disruption of avoidance responding.

On the first drug-free test session, avoidance responses to CS1 and CS2 in the two OLZ-treated groups

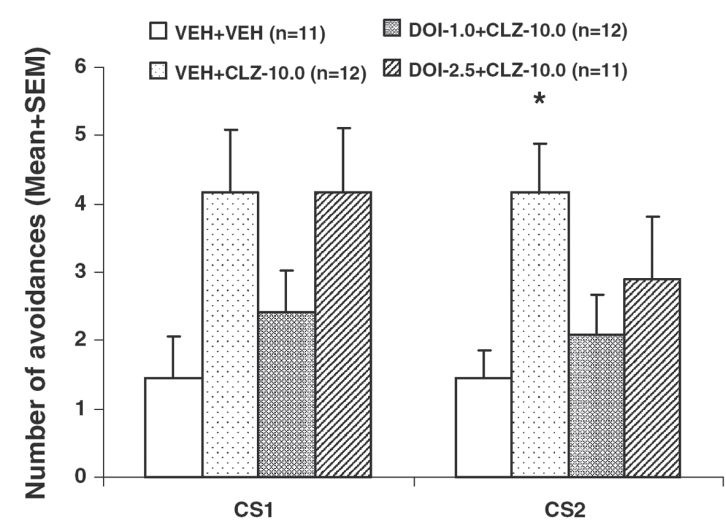

Figure 2. Effects of pretreatment of DOI on the repeated treatment effect of clozapine on CS1 and CS2 avoidance responses. Data are mean (+SEM) numbers of avoidance responses on the challenge test day. Rats that were previously treated with double vehicles, vehicle plus clozapine $(10.0 \mathrm{mg} / \mathrm{kg})$, or DOI $(1.0$ or $2.5 \mathrm{mg} / \mathrm{kg})$ plus clozapine $(10.0 \mathrm{mg} / \mathrm{kg})$ were challenged with clozapine $(5.0 \mathrm{mg} / \mathrm{kg}) .{ }^{*} p<0.05$ significantly different from the corresponding $\mathrm{VEH}+\mathrm{VEH}$ group
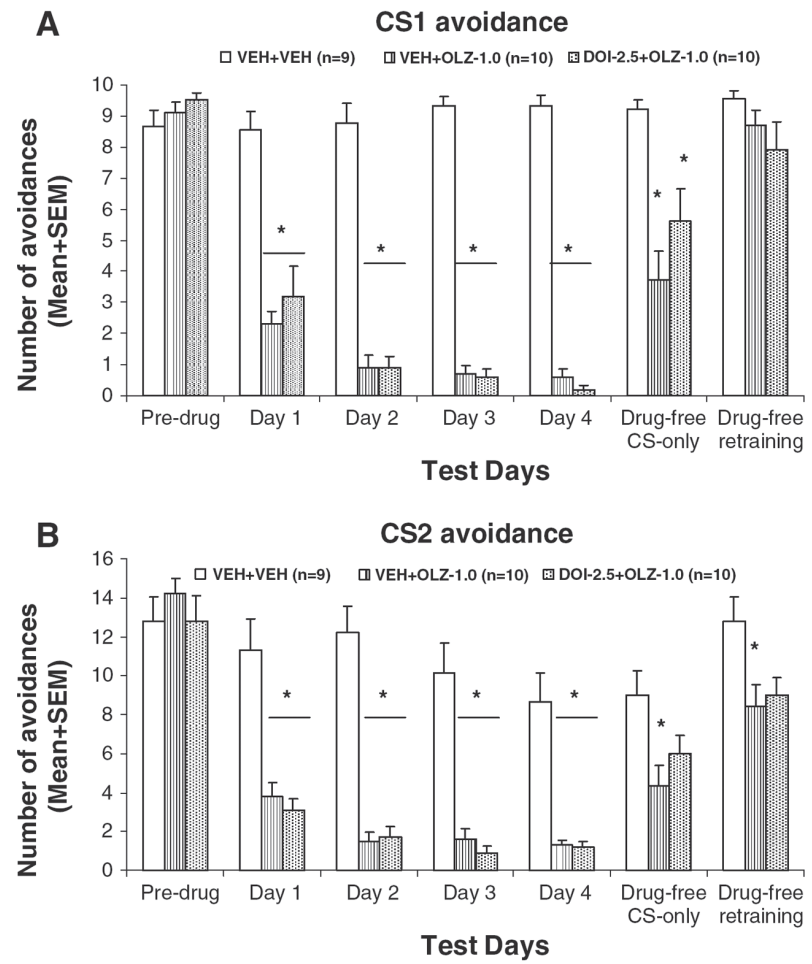

Figure 3. Effects of pretreatment of DOI on acute olanzapineinduced disruption of CS1 avoidance (a) and CS2 avoidance (b). Mean (+SEM) numbers of avoidance responses of the four groups of rats on the last CAR training day (pre-drug), four drug test days (Day 1 to Day 3), and two drug-free test days (drug-free CS-only and drug-free retraining). ${ }^{*} p<0.05$ significantly different from the $\mathrm{VEH}+\mathrm{VEH}$ group

recovered to some extent, but not to the level comparable to that of the vehicle. There was a main effect of group for the CS1 avoidance, $F(2,26)=10.554, p<0.001$, 
and the CS2 avoidance, $F(2,26)=4.738, p=0.018$. Post hoc tests showed that the VEH + OLZ group differed significantly from the VEH + VEH group on both types of avoidance (CS1: $p<0.001$; CS2: $p=0.014$ ), whereas the DOI-2.5 + OLZ group differed significantly from the VEH + VEH only on the CS1 avoidance $(p=0.016)$, but not on the CS2 avoidance $(p=0.146)$. On the second drug-free retraining session, there was still a main effect of group for the CS2 avoidance, $F(2,26)=4.462$, $p=0.022$. Post hoc tests showed that the VEH + OLZ group differed significantly from the $\mathrm{VEH}+\mathrm{VEH}$ group on the CS2 avoidance ( $p=0.026)$.

On the drug challenge test during which all rats were acutely injected with OLZ at $0.5 \mathrm{mg} / \mathrm{kg}$ (Figure 4), rats previously treated with VEH + OLZ or DOI-2.5 + OLZ made fewer avoidances than the VEH + VEH rats, indicating a strong sensitization-like effect of repeated OLZ treatment. One-way ANOVA revealed a main effect of group on the CS1 avoidance, $F(2,26)=9.329, p=0.001$, and the CS2 avoidance $F(2,26)=6.662, p=0.005$. Posthoc tests indicated that VEH + OLZ and DOI-2.5 + OLZ groups all differed significantly from the $\mathrm{VEH}+\mathrm{VEH}$ group on the CS1 and CS2 avoidance (all ps < 0.013), suggesting that pretreatment of DOI failed to alter the long-term OLZ sensitization effect.

\section{Discussion}

The present study further demonstrated an interesting dissociated serotonin receptor mechanism underlying acute and repeated effects of clozapine and olanzapine on avoidance responding. On the acute effect side, we observed that pretreatment of DOI dose-dependently reversed the clozapine-induced disruption, but had no effect on olanzapine-induced one. On the repeated effect side, we confirmed that repeated administration of clozapine produces a tolerance-like effect, whereas repeated administration of olanzapine produces a sensitization-like effect. Importantly, pretreatment of DOI failed to alter both effects, suggesting that $5-\mathrm{HT}_{2 \mathrm{~A} / 2 \mathrm{C}}$ receptor is not likely to be involved in the repeated effects of clozapine and olanzapine.

The modified CAR paradigm was utilized in the present study to verify the receptor mechanisms of clozapine and olanzapine as identified in our previous report ( $\mathrm{Li}$ et al. 2010) and to ensure our finding is not the artifact of any specific CAR setup. Despite the procedural difference, we still observed that pretreatment of DOI dose-dependently reversed clozapine-induced disruption of avoidance but had no effect on olanzapineinduced disruption, a finding consistent with our previous work ( $\mathrm{Li}$ et al. 2010) in which we only used one avoidance response (CS1). We did notice two slightly different findings between the present clozapine study

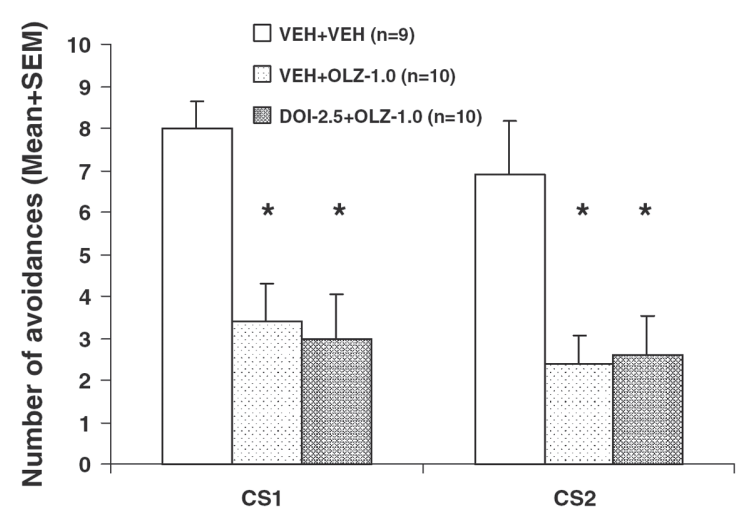

Figure 4. Effects of pretreatment of DOI on the repeated treatment effect of olanzapine on CS1 and CS2 avoidance responses. Data are mean (+SEM) numbers of avoidance responses on the challenge test day. Rats that were previously treated with double vehicles, vehicle plus olanzapine $(1.0 \mathrm{mg} /$ $\mathrm{kg})$, or DOI $(2.5 \mathrm{mg} / \mathrm{kg})$ plus olanzapine $(1.0 \mathrm{mg} / \mathrm{kg})$ were challenged with olanzapine $(0.5 \mathrm{mg} / \mathrm{kg}) .{ }^{*} p<0.05$ significantly different from the corresponding $\mathrm{VEH}+\mathrm{VEH}$ group

and the previous one. One is that the reversal effect of DOI $2.5 \mathrm{mg} / \mathrm{kg}$ seems stronger and more complete than the effect found in the previous study. For example, on the first drug day, the mean number of CS1 avoidance in the DOI-2.5 + CLZ group was $86 \%$ of that in the $\mathrm{VEH}+\mathrm{VEH}$ group in the present study, whereas it was only $46 \%$ of the VEH + VEH in the previous study. The second difference is that the DOI's reversal effect diminished over the test sessions in the present study, whereas it remained stable in the previous study. These results suggest that although specific parameters used in a CAR procedure may not be critical in revealing the neuroreceptor mechanisms of action of antipsychotic drugs, they could influence the direction and magnitude of the behavioral effects of drugs, a phenomenon best known as the "rate-dependent drug effects" (Dews 1976; Spealman et al. 1983; Barrett 2002; McMillan and Katz 2002; Barrett and Bergman 2008). The present finding, together with our previous maternal behavior studies in which we showed that pretreatment of DOI, but not quinpirole, dose-dependently reversed the clozapine-induced disruption of rat maternal behavior (Zhao and Li 2009, 2010), provides a strong support that clozapine achieves its behavioral effects mainly by blocking $5-\mathrm{HT}_{2 \mathrm{~A} / 2 \mathrm{C}}$ receptors.

Because olanzapine, like clozapine, has a potent antagonist action on $5-\mathrm{HT}_{2 \mathrm{~A} / 2 \mathrm{C}}$ receptors, it is somewhat surprising to see this dissociated DOI effect on these drugs. However, it should be noted that olanzapine has a much lower 5- $\mathrm{HT}_{2 \mathrm{~A} / 2 \mathrm{C}}$ affinity, but a much higher $\mathrm{D}_{2}$ receptor affinity than clozapine (Meltzer et al. 2003). Furthermore, olanzapine has a slower dissociation rate ( $k$ off value) from the $\mathrm{D}_{2}$ receptor than clozapine (Kapur and Seeman 
2001). More importantly, its $D_{2}$ receptor occupancy predicts its clinical effect better than its $5-\mathrm{HT}_{2 \mathrm{~A} / 2 \mathrm{C}}$ receptor occupancy (Kapur et al. 1999, 2000). These differences in molecular mechanisms of action may explain the differences between olanzapine and clozapine in response to the DOI pretreatment. Because olanzapine's $\mathrm{D}_{2}$ occupancy correlates well with its disruptive effect on avoidance response (Wadenberg et al. 2001; Olsen et al. 2008), it is thus likely that olanzapine's avoidance disruptive effect is mainly mediated by its action on $\mathrm{D}_{2}$ receptor but not on $5-\mathrm{HT}_{2 \mathrm{~A} / 2 \mathrm{C}}$ receptor. Our previous finding that pretreatment of quinpirole, a selective dopamine $\mathrm{D}_{2 / 3}$ agonist attenuates the acute olanzapine-induced disruption of avoidance response is consistent with this hypothesis. The lack of involvement of $5-\mathrm{HT}_{2 \mathrm{~A} / 2 \mathrm{C}}$ receptors in the avoidance-disruptive effect of olanzapine is also consistent with human brain imaging work suggesting that for olanzapine, $\mathrm{D}_{2}$ receptor occupancy alone can explain its antipsychotic effect (Kapur et al. 1999).

Because clozapine has a dual action on both $5-\mathrm{HT}_{2 \mathrm{~A}}$ and $5-\mathrm{HT}_{2 \mathrm{C}}$ receptors, and DOI is nonselective for $5-\mathrm{HT}_{2 \mathrm{~A}}$ versus $5-\mathrm{HT}_{2 \mathrm{C}}$ receptors, it is not certain which serotonin receptor is responsible for DOI's reversal effect and the avoidance disruptive effect of clozapine. As we have discussed earlier ( $\mathrm{Li}$ et al. 2010), we speculate that the $5-\mathrm{HT}_{2 \mathrm{~A}}$, but not $5-\mathrm{HT}_{2 \mathrm{C}}$ receptor, may be more important. This idea is supported by the findings that selective $5-\mathrm{HT}_{2 \mathrm{C}}$ receptor agonists are generally ineffective in counteracting clozapine (Ichikawa et al. 2001), and many behavioral and molecular effects of DOI are found to be mediated by its antagonism on $5-\mathrm{HT}_{2 \mathrm{~A}}$ receptors, and not on 5- $\mathrm{HT}_{2 \mathrm{C}}$ receptors (Schreiber et al. 1995; Sipes and Geyer 1995, 1997; Smith et al. 2003; Halberstadt et al. 2009). Future work using more selective $5-\mathrm{HT}_{2 \mathrm{~A}}$ and $5-\mathrm{HT}_{2 \mathrm{C}}$ receptor agonists may help determine the relative contribution of these two serotonin receptor subtypes in the mediation of the avoidance disruptive effect of clozapine. Clozapine has high affinity for adrenergic $\mathrm{a}_{1}$ receptor, muscarinic $\mathrm{M} 1$ receptor, and histamine $\mathrm{H}_{1}$ receptor and moderate affinity for the $\mathrm{D}_{4}$ and $5-\mathrm{HT}_{6}$ receptors, its actions on these receptors may also contribute to its avoidance-disruptive effect.

In our previous study, we have used a similar modified CAR paradigm to examine the motivational salience attenuation action of antipsychotic treatment $(\mathrm{Li}$ et al. 2009b; Zhang et al. 2011). We found that olanzapine and risperidone disrupt the CS2 (a less salient conditioned stimulus) avoidance to a greater extent than the CS1 avoidance. Although it was not the focus of the current study, the preferential action against the CS2 avoidance over the CS1 avoidance by olanzapine and clozapine was also apparent. For example, on the first drug test day, the VEH + CLZ rats made $12.5 \%$ CS1 avoidance, but only $4.17 \%$ CS2 avoidance. Similarly, the $\mathrm{VEH}+$ OLZ rats made 23\% CS1 avoidance but 19\% CS2 avoidance. Another piece of supporting evidence was that the impaired CS1 avoidance in the VEH + OLZ group recovered completely on the drug-free retraining session, while the CS2 avoidance did not. Finally, the reversal effect of DOI pretreatment on clozapine-induced CS1 disruption lasted longer (2 days) than its effect on CS2 disruption (1 day), indirectly reflecting the stronger and preferential action of clozapine against the CS2 avoidance over the CS1 avoidance. This finding may explain that antipsychotic drugs achieve their clinical effects on psychosis by selectively attenuating the motivational salience of psychotic thoughts and perception ( $\mathrm{Li}$ et al. 2004b, 2007).

The present study further confirmed the existence of a clozapine-induced tolerance effect and an olanzapine-induced sensitization effect in the CAR model. This kind of repeated effect is evidenced by the finding that the VEH + CLZ rats made significantly more avoidance responses, and the VEH + OLZ rats made significantly fewer avoidance responses than the VEH + VEH rats in the drug challenge test (Li et al. 2007, 2009a, 2010; Mead and Li 2010). Consistent with our previous findings, pretreatment of DOI did not alter both types of repeated effects, indicating that the long-term effects of clozapine and olanzapine are not mediated by their actions on the $5-\mathrm{HT}_{2 \mathrm{~A} / 2 \mathrm{C}}$ receptor system. In our previous study, we showed that pretreatment of quinpirole attenuated olanzapine-induced sensitization effect, but potentiated clozapine-induced tolerance, suggesting that the repeated effect of clozapine and olanzapine may be commonly mediated by their action on the $\mathrm{D}_{2 / 3}$ receptor system (Atkins et al. 1999; Kapur et al. 2003; MoranGates et al. 2006). Overall, findings from the previous study and the present one collectively revealed dissociated dopamine and serotonin receptor systems underlying the acute and repeated effects of clozapine and olanzapine. One important future project is to delineate the neuroadaptive changes induced by repeated antipsychotic treatment that are mediated by these and other receptor systems (e.g. 5- $\mathrm{HT}_{1 \mathrm{~A}}, \mathrm{D}_{1}, \mathrm{D}_{4}$, etc.) and identify their clinical relevance.

Acknowledgments - This study was supported in part by the NIMH grant (R01MH085635) to Professor Ming Li. We thank Ms. Natashia Swalve and Heidi Gonzalez for their editorial help.

\section{References}

Ader R, Clink DW (1957) Effects of chlorpromazine on the acquisition and extinction of an avoidance response in the rat. J Pharmacol Exp Ther 131:144-148

Arnt J (1982) Pharmacological specificity of conditioned avoidance response inhibition in rats: inhibition by neuroleptics and correlation to dopamine receptor blockade. Acta Pharmacol Toxicol (Copenh) 51:321-329 
Atkins JB, Chlan-Fourney J, Nye HE, Hiroi N, Carlezon WA Jr, Nestler EJ (1999) Region-specific induction of deltaFosB by repeated administration of typical versus atypical antipsychotic drugs. Synapse 33:118-128

Barrett JE (2002) The emergence of behavioral pharmacology. Mol Interv 2:470-475

Barrett JE, Bergman J, Peter B (2008) Dews and pharmacological studies on behavior. J Pharmacol Exp Ther 326:683-690

Chen J, Wang Z, Li M (2011) Multiple 'hits' during postnatal and early adulthood periods disrupt the normal development of sensorimotor gating ability in rats. J Psychopharmacol 25:379-392

Dews PB (1976) Interactions of behavioral effects of drugs. Ann N Y Acad Sci 281:50-63

Geyer MA, Krebs-Thomson K, Braff DL, Swerdlow NR (2001) Pharmacological studies of prepulse inhibition models of sensorimotor gating deficits in schizophrenia: a decade in review. Psychopharmacology (Berl) 156:117-154

Granoff MI, Ashby CR Jr (1998) The effect of the repeated administration of the compound 3, 4-methylenedioxymethamphetamine on the response of rats to the 5-HT2A, C receptor agonist ( \pm )-1-(2, 5-dimethoxy-4-iodophenyl)2-aminopropane (DOI). Neuropsychobiology 37:36-40

Halberstadt AL, van der Heijden I, Ruderman MA, Risbrough VB, Gingrich JA, Geyer MA, Powell SB (2009) 5-HT(2A) and 5-HT(2C) receptors exert opposing effects on locomotor activity in mice. Neuropsychopharmacology 34:1958-1967

Ichikawa J, Dai J, Meltzer HY (2001) DOI, a 5-HT2A/2C receptor agonist, attenuates clozapine-induced cortical dopamine release. Brain Res 907:151-155

Kapur S, Seeman P (2001) Does fast dissociation from the dopamine $d(2)$ receptor explain the action of atypical antipsychotics?: A new hypothesis. Am J Psychiatry 158:360-369

Kapur S, Zipursky RB, Remington G (1999) Clinical and theoretical implications of 5-HT2 and D2 receptor occupancy of clozapine, risperidone, and olanzapine in schizophrenia. Am J Psychiatry 156:286-293

Kapur S, Zipursky R, Jones C, Remington G, Houle S (2000) Relationship between dopamine $\mathrm{D}(2)$ occupancy, clinical response, and side effects: a double-blind PET study of first-episode schizophrenia. Am J Psychiatry 157:514-520

Kapur S, VanderSpek SC, Brownlee BA, Nobrega JN (2003) Antipsychotic dosing in preclinical models is often unrepresentative of the clinical condition: a suggested solution based on in vivo occupancy. J Pharmacol Exp Ther 305:625-631

Li M, Davidson P, Budin R, Kapur S, Fleming AS (2004a) Effects of typical and atypical antipsychotic drugs on maternal behavior in postpartum female rats. Schizophr Res 70:69-80

Li M, Parkes J, Fletcher PJ, Kapur S (2004b) Evaluation of the motor initiation hypothesis of APD-induced conditioned avoidance decreases. Pharmacol Biochem Behav 78:811-819

Li M, Fletcher PJ, Kapur S (2007) Time course of the antipsychotic effect and the underlying behavioral mechanisms. Neuropsychopharmacology 32:263-272

Li M, He W, Munro R (2008) Amphetamine selectively enhances avoidance responding to a less salient stimulus in rats. J Neural Transm 115:773-776
Li M, He W, Mead A (2009a) An investigation of the behavioral mechanisms of antipsychotic action using a drugdrug conditioning paradigm. Behav Pharmacol 20:184-194

Li M, He W, Mead A (2009b) Olanzapine and risperidone disrupt conditioned avoidance responding in phencyclidinepretreated or amphetamine-pretreated rats by selectively weakening motivational salience of conditioned stimulus. Behav Pharmacol 20:84-98

Li M, Sun T, Zhang C, Hu G (2010) Distinct neural mechanisms underlying acute and repeated administration of antipsychotic drugs in rat avoidance conditioning. Psychopharmacology (Berl) 212:45-57

Li M, He W, Chen J (2011) Time course of prepulse inhibition disruption induced by dopamine agonists and NMDA antagonists: effects of drug administration regimen. Pharmacol Biochem Behav 99:509-518

McMillan DE, Katz JL (2002) Continuing implications of the early evidence against the drive-reduction hypothesis of the behavioral effects of drugs. Psychopharmacology (Berl) 163:251-264

Mead A and Li M (2010) Avoidance-suppressing effect of antipsychotic drugs is progressively potentiated after repeated administration: an interoceptive drug state mechanism. J Psychopharmacol 24(7):1045-1053

Mead A, Li M, Kapur S (2008) Clozapine and olanzapine exhibit an intrinsic anxiolytic property in two conditioned fear paradigms: contrast with haloperidol and chlordiazepoxide. Pharmacol Biochem Behav 90:551-562

Meltzer HY, Li Z, Kaneda Y, Ichikawa J (2003) Serotonin receptors: their key role in drugs to treat schizophrenia. Prog Neuropsychopharmacol Biol Psychiatry 27:1159-1172

Moran-Gates T, Gan L, Park YS, Zhang K, Baldessarini RJ, Tarazi FI (2006) Repeated antipsychotic drug exposure in developing rats: dopamine receptor effects. Synapse 59:92-100

Olsen CK, Brennum LT, Kreilgaard M (2008) Using pharmacokinetic-pharmacodynamic modelling as a tool for prediction of therapeutic effective plasma levels of antipsychotics. Eur J Pharmacol 584:318-327

Russig H, Murphy CA, Feldon J (2003) Prepulse inhibition during withdrawal from an escalating dosage schedule of amphetamine. Psychopharmacology (Berl) 169:340-353

Schreiber R, Brocco M, Audinot V, Gobert A, Veiga S, Millan MJ (1995) (1-(2, 5-dimethoxy-4 iodophenyl)2-aminopropane)-induced head-twitches in the rat are mediated by 5-hydroxytryptamine $(5-\mathrm{HT})$ 2A receptors: modulation by novel 5-HT2A/2C antagonists, D1 antagonists and 5-HT1A agonists. J Pharmacol Exp Ther 273:101-112

Sipes TE, Geyer MA (1995) DOI disruption of prepulse inhibition of startle in the rat is mediated by $5-\mathrm{HT}(2 \mathrm{~A})$ and not by 5-HT(2C) receptors. Behav Pharmacol 6:839-842

Sipes TE, Geyer MA (1997) DOI disrupts prepulse inhibition of startle in rats via 5-HT2A receptors in the ventral pallidum. Brain Res 761:97-104

Smith RL, Barrett RJ, Sanders-Bush E (2003) Discriminative stimulus properties of 1-(2, 5-dimethoxy-4-iodophenyl)2-aminopropane $[( \pm) \mathrm{DOI}]$ in C57BL/6J mice. Psychopharmacology (Berl) 166:61-68 
Spealman RD, Kelleher RT, Goldberg SR, DeWeese J, Goldberg DM (1983) Behavioral effects of clozapine: comparison with thioridazine, chlorpromazine, haloperidol and chlordiazepoxide in squirrel monkeys. J Pharmacol Exp Ther 224:127-134

Sun T, He W, Hu G, Li M (2010) Anxiolytic-like property of risperidone and olanzapine as examined in multiple measures of fear in rats. Pharmacol Biochem Behav 95:298-307

Wadenberg ML, Hicks PB (1999) The conditioned avoidance response test re-evaluated: is it a sensitive test for the detection of potentially atypical antipsychotics? Neurosci Biobehav Rev 23:851-862

Wadenberg ML, Soliman A, VanderSpek SC, Kapur S (2001) Dopamine $\mathrm{D}(2)$ receptor occupancy is a common mecha- nism underlying animal models of antipsychotics and their clinical effects. Neuropsychopharmacology 25:633-641

Zhang C, Fang Y, Li M (2011) Olanzapine and risperidone disrupt conditioned avoidance responding by selectively weakening motivational salience of conditioned stimulus: further evidence. Pharmacol Biochem Behav 98:155-160

Zhao C, Li M (2009) The receptor mechanisms underlying the disruptive effects of haloperidol and clozapine on rat maternal behavior: a double dissociation between dopamine $\mathrm{D}(2)$ and 5-HT(2A/2C) receptors. Pharmacol Biochem Behav 93(4):433-442

Zhao C, Li M (2010) C-Fos identification of neuroanatomical sites associated with haloperidol and clozapine disruption of maternal behavior in the rat. Neuroscience 166:1043-1055 